\title{
TRAINING OF FORESTERS
}

\section{By G. DUMAINE ${ }^{1}$}

\section{INTRODUCTION}

Last fall, when flying back from Winnipeg, I was reminiscing about the difficulties and the stage-fright $I$ had encountered when attending a meeting at which I had to deliver a paper in my second language, English.

I then resolved to practice my second language more often; at the office, on the street, at all times, in all places, even at home.

At the airport, all the family was waiting for me. Embracing everyone, I carried out my resolution and I said: "Hello everybody, are you glad to see your dad back?" Nobody answered, not even my wife.

Driving home, my son asked me: "Dad, is it true as mommy said ... that you are obliged to take a drink when travelling by plane?"

My family was not prepared for this new way of communication, they should have been warned and trained before I started to put this bright idea into practice.

\section{Good Training Programme-Hard To Apply}

For most industries and Government authorities, the main problem in training with efficiency a young technical man, especially a young forester, is not so much what they have to communicate to him; it is how, through what channel and by what means the communication should be made.

For most members of a senior staff when a young technician joins their organization, their routine work is disturbed, they are obliged to supervise and give an indoctrination very hard to give, especially to a young talented man; even if the senior knows this brand new mind has been hired for the ultimate purpose of increasing the efficiency of actual practices, he will be cold towards good new ideas brought up and he will be irritated on being plied with all kinds of questions.

Assuredly, the young man notices this intolerance; surprised, he may be suspicious in face of these unconscious reactions which have, as a final result, a lack of communication.

\section{How To Train}

Everyone realizes that we continuously have to change our trend of thought and we need also to review the way we communicate our experience to the young technician when introducing him in our respective organizations.

Before dealing with some specific suggestions on our topic, may I give you one basic concept which, in my opinion, is of an absolute necessity for obtaining real success in training.

${ }^{2}$ District Personnel Supervisor, St. Anne Power Co., Beaupre, P.Q. 
"Subordinates receive too many definite answers and are not asked often enough for suggestions and recommendations." The opposite concept derives naturally from a persuasive type of leadership taking into consideration the human element in all its complexity with all its differences of the physical, mental and moral capabilities of that individual.

A young forester when starting a career in the industry is not prepared to be fully integrated; he does not have the flexibility to be adaptable to this mesh of circumstances; such as: variety in personalities, variety of interests sometimes in a fair business management and fair labor management; he then should pass through this transition period from the status of a hardworking student to a hard-working employee, in working on specific studies of particular interest to his company.

\section{EXAMPLE}

To illustrate my idea, let me give you an example taken from a logging department, a field which requires part of the forester's knowledge of forestry, engineering and human relations, a field which is particularly familiar to most of you.

A young forester, at his first job in a logging department, should make a complete study of a specific area to be logged: such a study would require: Logging inventory, Classification of wood and ground conditions, Location of roads, Estimate of cost for improvements, Estimate of cost for the various logging methods.

After completion of these preliminary studies, the forester should be asked to take a junior part in the operation, the supervision and control of his own plan. He should be asked to note and report errors and successes, his observations and suggestions for the improvement of production, equipment, living conditions, employee relations and finally for the reduction of costs.

His studies should be prepared and reported like the thesis he defended before the University Examination Board.

His thesis would be prepared in the field of the production line in which a lot of minor problems will crop up every day which he will help to solve.

He should be put in a position where he could realize how many errors the engineer or technician can make when he first attempts to supervise employees on production, where he can discover his responsibilities and duties.

He should be put in a position where he could note the reaction of workers and management, the acceptance of supervision and new methods, where he could try to find the secret for winning respect, confidence and loyalty from subordinates, where he can train himself in communication techniques with workers and with top management, in giving orders or in drafting reports, writing memos and delivering talks at local meetings.

This completed report on his first job as a engineer should be considered as a thesis to be defended in front of management authorities who currently will judge if he is really preparing to be integrated in the executive of the company. 
It means that: a young man, during the first and second years with a company, should be considered as a post-graduate using the company limits in full activity as a laboratory where his university work continues, where this young talented and alert "authority still in embryo" will live without being upset too much, where new ideas and new methods can be drawn out and used for benefit.

This young man at this transitory stage will learn how to differentiate between two very distinct authorities: the professor .... the theoretician; the boss ... the practical man.

During this period, his illusions as a new engineer will not be completely extinct because he will have realized by himself that he is far from knowing all about his career, that he will have to analyze and study continuously to put into practice all his knowledge. He will understand that academic success obtained at the University gave him only an easy way to be admitted to the field of operation, and, if he wants to take the lead in this field, he will be obliged to learn by experience, with much more serious thought, at times under stress, with discipline, all those things necessary to acquire that experience.

\section{CONCLUSION}

The success in the application of new methods in the production and in the management programs is not based exclusively on the intrinsic value of the genius idea but also on the various circumstances affecting the execution of technical changes.

A young forester, instructed and educated by the University, well trained by his employer and working with skilled workers in an encouraging and creative atmosphere, elaborated by the management personnel, is only too anxious to be fully integrated in this kind of productive concept. He will be grateful to you for trying to apply these suggestions which $I$ have taken the liberty of proposing to you in this paper.

\section{(Continued from page 5 )}

distinguish between necessary education and temporary fillers. I also believe that "outside pressures" can have a detrimental effect in the long run while appearing to offer advantages in the present. I offer as an example "Design of curriculum to take advantage of employment trends".

Forestry is a specialized education and the University Forestry graduate is looked upon by some people as the lower class of a University Graduate.

We need an accrediting body of foresters to keep continuous contact with our Forestry Schools to ensure the upgrading of Forestry education. The body appointed must be a national body so why the inaction by the C.I.F.?

JOHN W. HAGGERTY

Assoc. Prof. of Forestry

Lakehead College, Port Arthur 